\title{
Role of diapause in dispersal and invasion success by aquatic invertebrates
}

\author{
Vadim E. PANOV*, Piotr I. KRYLOV and Nicoletta RICCARDI ${ }^{1)}$ \\ Zoological Institute of the Russian Academy of Sciences, University emb., 1, 199034, St. Petersburg (Russia) \\ ${ }^{1)}$ CNR Institute of Ecosystem Study, L.go V. Tonolli 50, 28922 Verbania Pallanza, Italy \\ *e-mail corresponding author: rbic@zin.ru
}

\begin{abstract}
Review of existing literature shows an important role of diapause in dispersal of aquatic invertebrates. There is evidence that among aquatic invertebrates, the role of diapause in dispersal can be important in crustaceans, specifically for species that produce resting eggs. Analysis of dispersal vectors of diapausing species revealed the increasing role of human-mediated vectors of species dispersal during last century (intentional and unintentional introductions, specifically associated with shipping) in comparison with natural vectors (currents, wind, birds). Generally, the role of human-mediated vectors is most important for species dispersal across geographical barriers and into large aquatic ecosystems affected by shipping. Current human-mediated transport vectors increase rates of aquatic species introductions in many orders of magnitude in comparison with historical nature-driven species dispersal rates. Ability to develop diapausing resting stages facilitates species survival during movement across geographical barriers under extreme conditions, such as in ballast tanks of ships. Case studies for invasive species of Cladocera show that some invaders may possess adaptive life cycles, switching to the early prolonged gamogenetic reproduction, which facilitates their invasion success into novel ecosystems and further dispersal by both natural and human-mediated vectors.
\end{abstract}

Key words: diapause, invasive species, dispersal, biological invasions, invasion success, Cladocera

\section{INTRODUCTION}

The problem of the degree and mode of dispersal of aquatic invertebrates, first considered by Forel in classic ecological treatise "Le Leman" (1892, 1895, 1904), has attracted the growing attention of biologists (Shurin 2000; Bilton et al. 2001; De Meester et al. 2002; Cáceres \& Soluk 2002; Figuerola \& Green 2002; Havel et al. 2002; Bohonak \& Jenkins 2003; Havel \& Shurin 2004). These papers provide a broad range of opinions (sometimes contradictory) concerning the scales, rates, and relative importance of various vectors in dispersal of aquatic organisms. The traditional paradigm that "the dispersal of aquatic invertebrates is frequent and widespread" was questioned by Bohonak \& Jenkins (2003). They argued that the review of empirical data provides strong evidence for high potential for dispersal rather than evidence for high actual dispersal rates in many aquatic invertebrate taxa. A review by Bilton et al. (2001) also questioned long-distance passive dispersal of freshwater invertebrates, even of their resting stages. These assertions contradict numerous observations of drastic increases in rates of aquatic invertebrate invasions in marine, estuarine, and freshwater ecosystems worldwide during the last decades (Leppäkoski et al. 2002). Exotic species can be considered as biological tracers that provide opportunities to examine patterns of dispersal among widely separated sites, and studies of their range expansions provide a model system for estimating rates at which aquatic invertebrates colonize new habitats (Havel et al. 1995; Havel et al. 2002).

Production of resistant propagules (eggs, cysts, gemmules or statoblasts) (embryonic diapause sensu Alekseev \& Starobogatov (1996) has been frequently considered as an adaptation for dispersal (Karlson 1992; Korovchinsky \& Boikova 1996; Fell 1998; Hairston 1998; Horne \& Martens 1998; Brendonck \& Riddoch 1999; Bilton et al. 2001). However, most studies have focused on conditions that promote the occurrence of resting eggs, factors that affect their survival and hatching from sediments, the presence of egg banks in sediments, and the impact of hatchlings from resting eggs on plankton community structure (Marcus 1996; Brendonck et al. 1998). In this paper we focus on impacts of diapause on dispersal of aquatic invertebrates, focusing primarily on planktonic organisms. First, we review major mechanisms and vectors of dispersal, both natural and human-mediated, of diapausing invertebrates. Second, we review four case studies of human-mediated transoceanic, of two of predatory and two of herbivorous cladocerans. We analyze their life history traits with emphasis on their ability to produce resistant propagules (resting eggs, ephippia), and on the ability of the propagules to tolerate environmental changes during transfer and colonization of novel habitats. Finally, we discuss the importance of diapausing stages in anthropogenic introductions and invasion success of aquatic invertebrates. 


\section{MECHANISMS AND VECTORS OF DISPERSAL OF DIAPAUSING INVERTEBRATES}

Diapausing invertebrates are by definition dispersed by external agents or vectors, which can be natural (surface water connections, ocean currents, wind, animals) or human-mediated. Human-mediated vectors have been discussed by many authors (Carlton 1996; Gollasch \& Leppäkoski 1999; Bilton et al. 2001; Minchin \& Gollasch 2002; Havel \& Shurin 2004). Dispersal by human vectors are usually viewed as "introductions", either intentional or unintentional (Carlton 1999). Below we briefly summarize natural and human vectors most important for dispersal of diapausing aquatic invertebrates.

\subsection{Natural vectors of dispersal}

Natural mechanisms and vectors of dispersal of aquatic invertebrates have been discussed in detail in recent reviews by Bilton et al. (2001), Bohonak \& Jenkins (2003), and Havel \& Shurin (2004). Diapausing eggs or cysts of aquatic invertebrates have been often considered as potential agents of dispersal by natural vectors, and even depicted in the literature as adaptations for dispersal (Maguire 1963; Korovchinsky \& Boikova 1996). However, the tactic of attaching propagules to firm substrata in some species of branchiopods which effectively reduces the chances of dispersal, may indicate more advantageous strategy of persistence of a population in a habitat (Fryer 1996).

Currents in marine ecosystems and rivers may be an important vectors for dispersal of active and diapausing invertebrates (Minchin \& Gollasch 2002; Havel \& Shurin 2004). Dispersal of gemmules of sponges by currents (as well as by fish, and waterfowl) is discussed by Fell (1998). A mid-summer shift towards sexual reproduction was observed by Makrushin (1984) in populations of the marine cladocerans Podon leuckarti and Evadne nordmanni in Northern Atlantic. He hypothesized that the ability to produce resting eggs throughout most of the summer season was an adaptation to the large-scale dispersal of Podon and Evadne by oceanic currents, which are an important natural dispersal vector for marine organisms. Shanks et al. (2003) compiled available information on the dispersal distance of the propagules of benthic marine organisms, and found a significant positive correlation between the duration of propagules in plankton and the dispersal distance, which ranged from minutes to months and meters to thousands of kilometers, respectively.

Wind dispersal of anostracan eggs may result only in their short-distance transport (Brendonck \& Riddoch 1999). In general, long-distance dispersal of diapausing stages as aerial plankton is unlikely (Bilton et al. 2001).

Short-distance transport of resistant diapausing eggs in fish stomachs is also potentially possible (Jarnagin et al. 2000), as well as by terrestrial animals (Maguire 1963), but significance of these vectors in nature is likely limited. However, fish guts as vector of dispersal of diapausing invertebrates can be important if coupled with human-mediated introductions of fish. For instance, Eurytemora affinis might have been introduced into San Francisco Bay through the introduction of striped-bass (Morone saxatilis) (Carol Lee pers. comm., see also Daphnia lumholtzi case study below).

Transfer of resting eggs by waterfowl can be considered as more effective vector of dispersal of invertebrates in inland waters (Bohonak \& Jenkins 2003), however direct evidence of its importance is also limited. Eggs may be dispersed by sticking to their legs and bills, within the plumage, and with ingested food, which frequently includes aquatic vegetation. It has been demonstrated that many waterfowl can carry resting stages and even individuals of freshwater crustaceans on their bodies and in their guts (Proctor 1964; Proctor et al. 1967).

A recent review by Figuerola \& Green (2002) showed that bird-mediated transport of propagules of aquatic invertebrates is a frequent process, but limited to local spatial scales. Results of the recent European Commission project LAKES (Long distance dispersal of Aquatic KEy Species) also did not provide evidence of long-distance dispersal of freshwater zooplankton by birds (Hobæk et al. 2002; M. Manca, personal communication). Low resistance to desiccation of some resting stages (Fell 1998) may limit distance of dispersal of diapausing aquatic invertebrates by waterbirds (Figuerola \& Green 2002). However, studies of genetic distributions of some zooplankton species along with analysis of major waterfowl flyways suggests a potentially significant role of birds in long-distance intracontinental dispersal of some cladocerans and bryozoans (Taylor et al. 1998; Freeland et al. 2000).

Assumptions of the significant role of dispersal of resting stages of freshwater invertebrates by natural factors were recently criticized in review by Bohonak \& Jenkins (2003), which suggested that genetic and direct experimental studies failed to demonstrate evidence of effective passive dispersal, specifically by wind (Jenkins 1995; Jenkins \& Underwood 1998; Cáceres \& Soluk 2002).

\subsection{Human-mediated dispersal}

Human-mediated dispersal vectors (introductions) are broadly classified into two main categories: deliberate or intentional introductions, and unintentional introductions. Regarding the first type of vector, Alekseev (1986) suggested that intentional transfers of crustaceans in latitudinal directions are hindered by genetically-fixed differences in timing of diapause, and successful acclimatization is more likely for crustaceans transferred after completion of diapause. In some cases, intentional long-distance transfers of target aquatic organisms for stocking purposes can be coupled with unintentional introductions of other organisms possessing diapause (see case study of Daphnia lumholtzi below). 
Recreational and commercial boating has shown to be an important vector for both short- and long-distance dispersal of aquatic invertebrates and their diapausing stages for inland waters of North America (Buchan \& Padilla 1999; Havel \& Stelzleni-Schwent 2000; Johnson \& Carlton 1996; Johnson et al. 2001). Some intercontinental transfers of diapausing eggs of aquatic invertebrates and their subsequent invasions of inland waters have been linked to the introduction of commercially useful plants (McKenzie \& Moroni 1986), importation of industrial equipment (see review by Havel \& Shurin 2004), and even transportation of the military amphibian vehicles (see case study of Daphnia parvula below). However, at present the majority of biological invasions into coastal and even inland waters worldwide can be linked to unintentional introductions via different shipping-related vectors: construction of canals, ships hull fouling and ballast water release. Ballast water of ships is a principal vector of global long-distance transfer of aquatic invertebrates and their resistant resting stages, which readily breaches geographic barriers to dispersal and gene flow (Carlton \& Geller 1993).

At minimum 367 distinctly identifiable taxa were represented in samples of ballast water from 159 cargo ships, arriving to the port at the U.S. west coast from 25 Japanese ports (Carlton \& Geller 1993). In this case study, certain taxa occurred in high densities: estimated copepod densities were greater than 1500 ind. $\mathrm{m}^{-3}$. Crustaceans predominate, and accounted for $31 \%$ of all taxa present, copepods present in $99 \%$ of sampled ships, barnacles in $83 \%$, and decapods crustaceans in $48 \%$ of sampled ships.

Results from European research based on surveys of ballast tanks water and sediments of 550 ships also indicated high biological diversity of aquatic communities within ballast water, which included 990 taxa of active organisms and their resting stages. Crustacea (240 taxa) were found to be the dominant faunal members of ballast tank communities, including as most diverse groups Calanoida (54 taxa), Harpacticoida (33 taxa) and Cladocera (28 taxa) (Gollasch et al. 2002), e.g. those groups that frequently possess embryonic or larval diapause. For example, Gollasch et al. (2000) recorded drastic changes in water temperature and composition of plankton community in ballast tanks of a container vessel on its 23-voyage from Singapore (Indian Ocean) to port in Germany (North Sea): while water temperature in ballast tanks declined two-fold, zooplankton species abundance and diversity decreased sharply, with only few organisms (mainly copepods) surviving and one species of an opportunistic harpacticoid copepod even increasing its abundance by a factor of 100 in one of the tanks. Such resistance of copepods to severe conditions in ballast tanks can be likely attributed to their ability to possess the larval diapause. It is likely, that harsh conditions in ship's ballast tanks (darkness, rapid changes in water temperature) may result in induction of embry- onic, larval or even adult diapause in some crustaceans, and thus facilitate their survival during ship journey.

Resting eggs and cysts of algae and aquatic invertebrates have been frequently reported in ballast tank sediments, which contains accumulations that varies from a few $\mathrm{cm}$ to more then $30 \mathrm{~cm}$ depth (Hamer 2002), resembling the upper layers of lake, estuarine or sea bottom sediments.

Bailey et al. (2003) recorded the presence of invertebrate diapausing eggs in residual sediments from transoceanic vessels and experimentally studied viability of the eggs collected from ballast tanks on vessels operating on the North American Great Lakes. In this study seventeen cladoceran, copepod, and rotifer taxa hatched from these sediments have been identified, and it have been showed that diapausing eggs in sediments may survive treatment of ballast tanks with oceanic water and could potentially hatch in dark ballast tanks if freshwater were added. The authors also suggested that tanks with independent ballast histories have different invasion risks.

In order to examine the potential of crustaceans to be transported by the shipping vector of dispersal, we conducted analysis of published data on the taxonomic diversity of alien invertebrates, introduced via shipping into four large semi-enclosed marine, estuarine and lacustrine ecosystems: Black Sea, Baltic Sea (Baltic can be considered as a large estuary), Caspian Sea (Caspian can be considered as a large brackishwater lake), and Great Lakes of North America. Our results show that in all studied ecosystems, the majority of introductions of alien species by ships belonged to crustaceans, with a clear trend of increasing role of crustacean invaders from marine ( $26 \%$ in the Black Sea) to freshwater ecosystem (46\% in the Great Lakes) (Fig. 1). While in the Black Sea introductions of crustaceans by ships were represented mainly by decapods (ballast water vector of dispersal) and barnacles (hull fouling), which are unlikely to possess diapause in their life cycles, significant part of crustaceans, introduced in the freshwater Great Lakes with ballast water, are dominated by cladocerans and copepods, e.g. taxa possessing strong diapause. This phenomenon may favor the hypothesis that the evolutionary appearance of embryonic diapause in crustaceans may facilitate the penetration of marine crustaceans into inland waters (Hairston \& Cáceres 1996; Hairston \& Bohonak 1998).

In an assessment model of the risk of future introductions of aquatic species with ballast waters into Great Lakes, considering species' invasions histories, shipping traffic patterns and physicochemical factors that constrain species survivorship during ballast-mediated transport, Grigorovich et al. (2003) identified 26 high-risk species. Among them 24 species belong to crustaceans, with more than half species possessing embryonal, larval or adult diapause ( 7 species of Cladocera and 6 species of Copepoda). The authors suggested that 

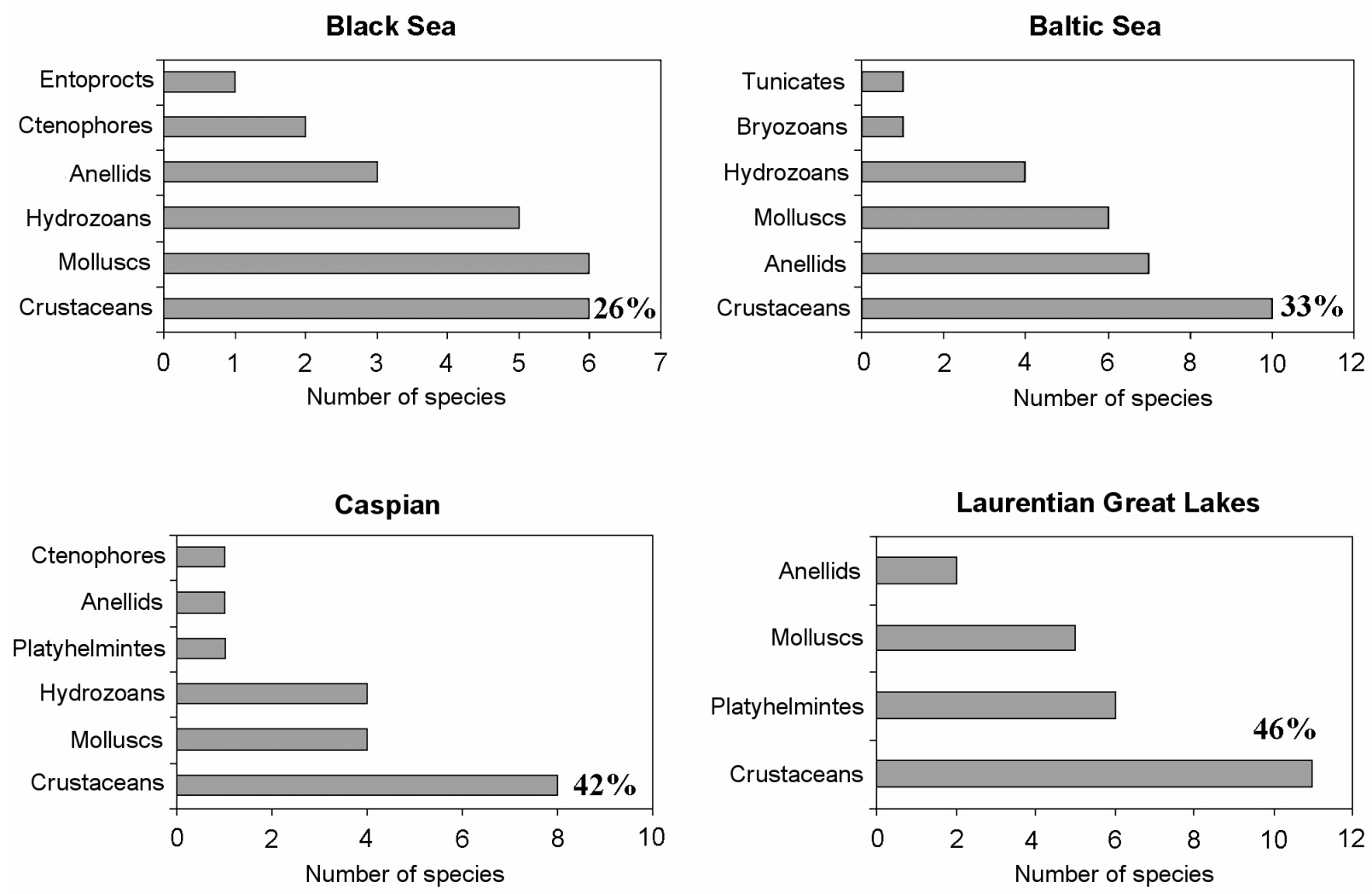

Fig. 1. Taxonomic diversity of aquatic invertebrates introduced via shipping. Data for the Black Sea and Caspian from Zaitsev \& Öztürk (2001), for the Baltic Sea from Olenin \& Leppäkoski (2001), for the Laurentian Great Lakes from Grigorovich et al. (2003).

ability to possess diapause, and/or parthenogenetic reproduction and short generation time in these taxa, already introduced into Great Lakes with ballast water, have fostered their survival during ballast-mediated transfer and ensured rapid population growth in ecosystems-recipients.

Shipping activity may facilitate invasion of freshwater ecosystems by freshwater, euryhaline and even marine species of crustaceans, including transfer of their diapausing stages. Introduction of saltwater copepod Eurytemora affinis in Mississippi River reservoirs (USA) from the Gulf of Mexico estuaries in 1930s1980s, which has been attributed to shipping traffic (Lee 1999), as well as establishment of euryhaline harpacticoid copepod Schizopera borutzkyi in Lake Michigan (Horvath et al. 2001), occurred, most likely, via diapausing stages of these species.

The results of the genetic analysis of European and North American lineages of freshwater cladocerans indicate that human-mediated vectors of dispersal may affect extraordinarily rates of intercontinental species dispersal: the current rates of species invasions are nearly 50,000 times higher than historical levels (Hebert \& Cristescu 2002). It is important, that most of these recent human-mediated intercontinental invasions originated, most likely, from transport of diapausing resting stages in ballast tanks of ships (see case studies for Bythotrephes longimanus and Cercopagis pengoi below).

\section{ROLE OF DIAPAUSE IN DISPERSAL AND INVASION SUCCESS: THE CASE STUDIES}

\subsection{Bythotrephes longimanus}

The Palearctic predatory cladoceran, "the spiny wateflea" Bythotrephes longimanus Leydig (Cladocera: Cercopagidae), was among the most successful zooplankton invaders to the North American continent, first found in Lake Ontario in 1982 (Johannsson et al. (1991), and by 1989 established in all Laurentian Great Lakes (Bur et al. 1986; Lange \& Cap 1986; Lehman 1987; Evans 1988; Cullis \& Johnson 1988; Jin \& Sprules 1990). Since then Bythotrephes has spread in many inland lakes of the Great Lakes basin (Yan et al. 1992; Yan \& Pawson 1997; MacIsaac et al. 2000).

Most probably, Bythotrephes was transferred from Europe to America with the ballast water of cargo vessels, presumably as diapausing resting eggs (Lehman 1987). As first supposed by Sprules et al. (1990), Lake Ladoga and Neva Estuary (eastern Gulf of Finland, Baltic Sea) could serve a source for Bythotrephes invasion. This hypothesis has been supported by the genetic study of Bythotrephes confirming the existence of the Lake Ladoga - Neva Estuary - Gulf of Finland Laurentian Great Lakes invasion corridor (Berg et al. 2002). 
Natural vectors, such as fish (Jarnagin et al. 2000) and waterfowl (Charalambidou et al. 2003), can play a role in the dispersal of Bythotrephes resting eggs. However, in North America B. longimanus is mainly spread by boaters and anglers attached to equipment such as fouled fishing lines, boat anchor lines, downrigger cables, via infected bilge water and live well water, and live minnow bait which contain females bearing resting eggs (Jarnagin et al. 2000; MacIsaac et al. 2004). MacIsaac et al. (2004) revealed that species spread occurred via a combination of dominant, local diffusion (median distance $12.5 \mathrm{~km}$ ) and rare, long-distance $(>100 \mathrm{~km})$ dispersal. For example, one invaded lake (Muskoka Lake, Ontario) apparently served as an invasion 'hub', resulting in up to 18 additional direct and 17 indirect invasions (MacIsaac et al. 2004).

Rapid short-distance dispersal of $B$. longimanus in North America was likely facilitated by changes in the reproductive strategy of this species. As most freshwater Cladocera, in native habitats Bythotrephes switches from parthenogenetic to gamogenetic reproduction at the end of a season and even then the densities of males and females with resting eggs are relatively low (Straile \& Hälbich 2000). Number of resting eggs per female Bythotrephes in the eastern Gulf of Finland varies usually between 2 and 3 with the maximum of 4 (Krylov et al. 2004). During some years, in the eastern basin of Lake Erie males and ephippial females appeared already in mid summer (Garton et al. 1993). In Lake Michigan in 1989 the beginning of production of resting eggs coincided with the population maximum in August (Burkhard 1994), although in the year 2000 gamogenetic females were recorded only in September (Pothoven et al. 2003). Mean number of resting eggs per female differed between 3.3 (Lake Michigan, 1993); 3.4 (Lake Superior, 1988); 3.6-4.0 (Lake Erie, 1988 and 1993); 5.04 (Lake Michigan, 2000); and 5.1 (Lake Huron, 1993) (Garton \& Berg 1990; Garton et al. 1990; Bilkovich \& Lehman 1997; Pothoven et al. 2003). Females bearing up to 7 resting eggs were recorded in Lake Erie in 1987 (Berg \& Garton 1988).

Even more remarkable changes in sexual reproduction were noted in Harp Lake (Ontario, Canada) where Bythotrephes appeared in the early 1990s. In 1994 and 1995 , females with resting eggs were noted from July, and by the end of August 50 to $80 \%$ of females carried resting eggs (Yan \& Pawson 1998; Yan et al. 1992; N.D.Yan, T.W.Pawson, personal communication). Later, in 1998, the Harp Lake population returned to a more typical parthenogenetic mode of reproduction during summer: first females with resting eggs were recorded in late August (Yan et al. 2001). However, creation of a large pool of resting eggs in lake sediments during first years after invasion facilitated successful establishment of Bythotrephes population despite high fish predation (Coulas et al. 1998) and resulted in remarkable changes in the structure of zooplankton com- munity of this lake (Yan \& Pawson 1997; Yan et al. 2001; Yan et al. 2002).

In late 1980s, Bythotrephes longimanus successfully invaded several water bodies in Belgium and The Netherlands. Although exact vectors of this dispersal are unclear, cargo vessels transport along River Rhine (and, thus, ballast water exchange) could have played a role (Ketelaars \& Gille 1994). However, the study of life history traits of Bythotrephes in Biesbosch Reservoirs did not show any changes in the mode of reproduction. Few males and gamogenetic females were observed in the end of the summer season (Ketelaars et al. 1995).

\subsection{Cercopagis pengoi}

Cercopagis pengoi (Ostroumov) (Cladocera: Cercopagidae) is native to the Caspian, Aral and Azov seas and some river estuaries of the Black Sea. It is also found in several freshwater reservoirs of Dnepr and Don basins and brackish water lakes near the Black Sea coast estuaries, and is known to be able to spread from its native habitats to freshwater reservoirs of the Volga and Don basins (Mordukhai-Boltovskoi \& Galinski 1974; Mordukhai-Boltovskoi \& Rivier 1987).

In 1992 C. pengoi was found in the Baltic Sea area (Gulf of Riga and Gulf of Finland), a likely result of the discharge of ballast water (Ojaveer \& Lumberg 1995; Ojaveer et al. 2000). After these first records, Cercopagis pengoi was first found in the Neva River estuary in 1995, already at high densities, and since then it become a common zooplankton species in the eastern Gulf of Finland (Krylov et al. 1999; Panov et al. 1999; Panov et al. 2003). Later C. pengoi was reported from central and southern Baltic Sea, both from deep-water offshore locations and shallow lagoons (see Krylov et al. 2004, for review).

Like invading Bythotrephes longimanus in Harp Lake in first two years after its first record, the C. pengoi population became established in the Neva Estuary, and showed a remarkable reproductive strategy, producing a large number of resting eggs during summer months in 1996 (Panov et al. 1996; Krylov \& Panov 1998). The maximal registered during season (July October) and mean seasonal percentage of both males and gamogenetic females in C. pengoi population in the studied part of the Neva Estuary gradually declined during 1996 - 2000 (Fig. 2). However, despite significant decline in gamogenetic reproduction in $C$. pengoi after its invasion, switch to "normal" autumn gamogenetic reproduction, like found in the Bythotrephes in Harp Lake after 5 years after its first record, is still not happen in Cercopagis in the Neva Estuary.

In the intensively studied location in the Neva Estuary (zooplankton was sampled every 10-14 days during May - October from 1996 to 2003), C. pengoi successfully coexists with native cercopagid cladoceran Bythotrephes longimanus (source population for North American Great Lakes, see above). However, observed strong 


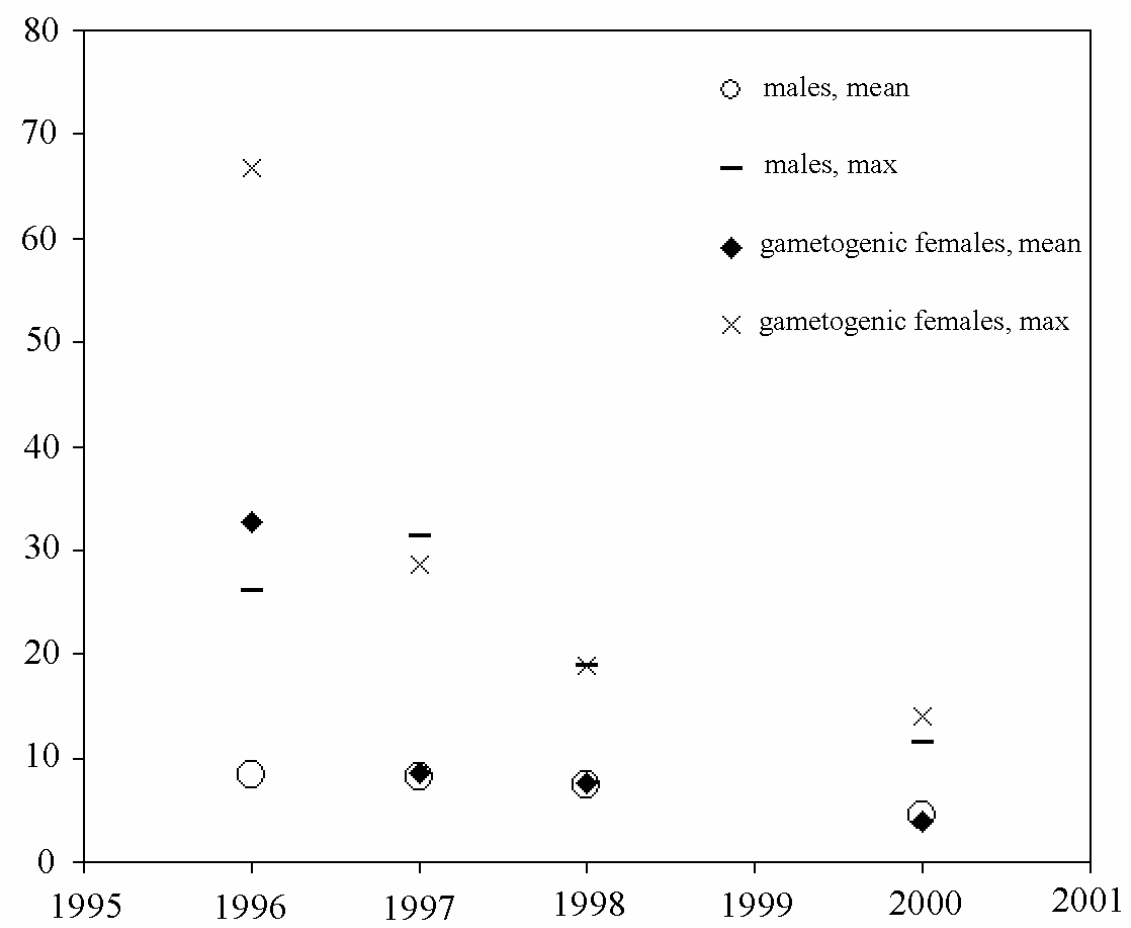

Fig. 2. Long-term changes in percentage of males and gamogenetic females in population of Cercopagis pengoi in the inner Neva Estuary, Baltic Sea (Panov \& Krylov, unpublished data).

seasonal and annual differentiation in development of $C$. pengoi and $B$. longimanus most likely reflect strong negative relationships between these predatory cladocerans, with bigger predator Bythotrephes suppressing Cercopagis. During summers in 1999 and 2001, with exceptional high densities of Bythotrephes in zooplankton, only few Cercopagis were recorded, so it was not possible to make estimations of its population structure. Despite severe negative relationships with native Bythotrephes and strong selective fish predation (Antsulevich \& Välipakka 2000), C. pengoi obviously successfully established in the Neva Estuary, even causing economic losses for local fishery via clogging fishing nets during its mass development (Panov et al. 1999).

It has been suggested that large pool of resting eggs in the Neva Estuary Cercopagis population has enabled this species to achieve fast population growth in new environments, and an increasing risk of C. pengoi being dispersed by ships' ballast water (Panov et al. 1996; Panov et al. 1999). In summer 1998 C. pengoi was found in Lake Ontario, snagged on sport fishing lines (MacIsaac et al. 1999). Most likely this is a question of secondary introduction by ships ballast waters from the eastern Baltic via an existing invasion corridor, identified in case of Bythotrephes invasion by Berg et al. (2002). Recent genetic study by Cristescu et al. (2001) demonstrated that the source population of Cercopagis in North American Great Lakes is most likely originated from the Baltic Sea population, namely Neva Estuary (eastern Gulf of Finland). From Lake Ontario, C. pengoi in few years spread to Lake Michigan, Lake Erie and some adjacent inland lakes (Charlebois et al. 2001; Therriault et al. 2002). Currently this species playing an important role in zooplankton of Lake Ontario, even suppressing some native zooplankton species (Ojaveer et al. 2001; Makarewicz et al. 2001; Benoit et al. 2002; Laxson et al. 2003; Makarewicz et al. 2003).

Populations of $C$. pengoi in Lake Ontario during first years after invasion also possess unusual midsummer sexual reproduction (Grigorovich et al. 2000; Makarewicz et al. 2001), characteristic for source population in the Baltic Sea (Neva Estuary), and for Bythotrephes in Harp Lake (see above). Despite existing potential of waterfowl to transfer of resting eggs of Cercopagis, boaters and ballast water of ships are considered as primary vectors of $C$. pengoi dispersal in Great Lakes area (Makarewicz et al. 2001). Potential for dispersal with fishing equipment for Cercopagis even higher, than for Bythotrephes, because specific morphological feature of its caudal appendage, which is longer and possesses terminal loop (this feature is reflected in North American common name of $C$. pengoi: "fishhook waterflea").

It is important to note that the invasion of C. pengoi to the Laurentian Great Lakes has been taken place after implementation of ballast water management options for the ships entering Great Lakes, namely exchange of ballast water in open ocean, which considered as effective measure to decrease risk of transfer of freshwater 
organisms. However, as it has been shown by Bailey et al. (2003), resting eggs of freshwater invertebrates may hatch also from the ballast water sediments, previously experienced influence of salt water. Thus, example of $C$. pengoi invasion to North America demonstrates the limited effectiveness of ballast water exchange programmes in preventing introductions of aquatic invertebrates producing resting eggs, which may accumulate in sediments of ballast tanks (MacIsaac et al. 1999).

\subsection{Daphnia parvula}

According to the hypothesis of Flössner \& Kraus (1976) Daphnia parvula Fordyce (Cladocera: Daphnidae) was introduced in Europe from North America by military amphibian vehicles which carried ephippia. Indeed, the first record (1972) of D. parvula in Europe (Flössner \& Kraus 1976) was in small water bodies lying in a area of SW Germany (Unterfranken) where maneuvers of U.S. Army pioneer troops frequently occurred during the 70 s. Contemporarily, D. parvula was found by Einsle in Lake Constance (Lake Superior, near Bregenz, Austria), and in 1973 in a small lake near Sächingen (SW Germany, Baden) (Flössner \& Kraus 1976; Einsle 1978, 1980). Subsequently, it was found in the River Neckar basin (near Stuttgart) and in the River Rhine basin (between Oppenheim and Karlsruhe) (1974), in NW Austria (Zell a. See, Salzburg) and in Spain (Duero and Guadalquivir River basins) (1975), in Belgium (1976), in Holland (1977), in Northern France and in South Germany (Altrhein-system) (1978), in Tirol (Reither See, Austria) (1980) and again in South Germany (near Ulm) in 1986 (Coussement et al. 1976; Frenzel 1976; Armengol 1978; Schrimpf \& Steinberg 1982; Schaber 1983; Herbst \& Anders 1987; Flössner 2000). Except for a single record in Bohemia (Western Czechoslovakia) (Korinek quoted in Hrbáček 1987) the diffusion to the Eastern European countries was delayed until the late '80s when it was found in South Macedonia and Bulgaria (1988), in Slovakia (1989) and in South Bohemia (1990) (Petkovski 1990; Flössner 2000; Stará et al. 2002). Until 2002, when it was recorded in Lake Candia (Northern Italy, Riccardi et al. 2004), the species was never found south of the Alps, which were traditionally considered a natural barrier to invasions.

Based on the available information, the dispersal rate of $D$. parvula seems lower than that of $D$. lumholtzi, and comparable to that of D. ambigua another North American invasive species in inland waters of Europe. According to Maier (1996) the rapid spread of D. lumholtzi is facilitated by its ability of making use of an open niche; conversely, invading the niche and co-existing with native species probably decelerated the dispersal of D. ambigua in Europe. The same reasoning could be valid for $D$. parvula which frequently co-occur with $D$. ambigua occupying the same niches (Maier 1996; Riccardi, unpublished data).
According to Flössner (2000), both natural (waterbirds, surface water connections) and human-mediated vectors (e.g., transport and introduction of fish fingerlings; water transport related to the excavation of artificial basins and canals) are responsible for the quick species dispersal from Southern Germany to other European locations. However, the delay in the diffusion to East European countries seems to suggest a primary role of human-mediated vectors for long-distance dispersal because of the coincidental occurrence with the removal of the strongest political barrier to human movements: the Wall crashing (1989). The most probable vectors to Lake Candia are waterbirds, reaching the lake mainly from Germany and East Europe, or boats, periodically transported to the lake for boat racings.

After its first record in Lake Candia in early September 2002, D. parvula population rapidly increased with maximum in November 2002, and disappeared from zooplankton in December (Riccardi et al. 2004). Like Bythotrephes longimanus in Harp Lake and Cercopagis pengoi in Neva Estuary and Lake Ontario, the pioneer population of $D$. parvula in Lake Candia showed a high level of gamogenetic reproduction during most period of population development. Males production started at the onset of population growth preceding ephippia formation which increased from mid-October through November. Sex ratio ranged from 0.1 to 0.33 males per female with a maximum in October when males accounted for up the $24 \%$ of the total population density. The proportion of ephippia (free ephippia + ephippial females) on the total population density ranged from about 3 to $23 \%$. During the second year after invasion the proportion of males was still high from September to November (up to $24 \%$ on the total population) but ephippia production was strongly reduced (about 0.1 to $4 \%$ on total population).

The large pool of resting eggs produced by the pioneer population of $D$. parvula in Lake Candia could reflect a strategy to increase the probability of survival and establishment in the new environment. Unfortunately, information on the ecology and population dynamics of $D$. parvula in European environments is lacking thus preventing any possible conclusions about the generality of an enhanced gamogenetic reproduction upon invasion of new sites.

\subsection{Daphnia lumholtzi}

Daphnia lumholtzi Sars (Cladocera: Daphnidae) is native to Africa, Asia and Australia, was first found in North America in 1990, and after that it was found rapidly spreading across lakes and reservoirs in the southeastern USA (Havel \& Hebert 1993; Havel et al. 1995). Genetic markers revealed the similarity among the North American populations and those from Africa (Uganda) and Asia (Nepal), though sampling of populations was limited (Havel et al. 2000). Intentional introduction of the Nile perch (Lates niloticus) from Lake 


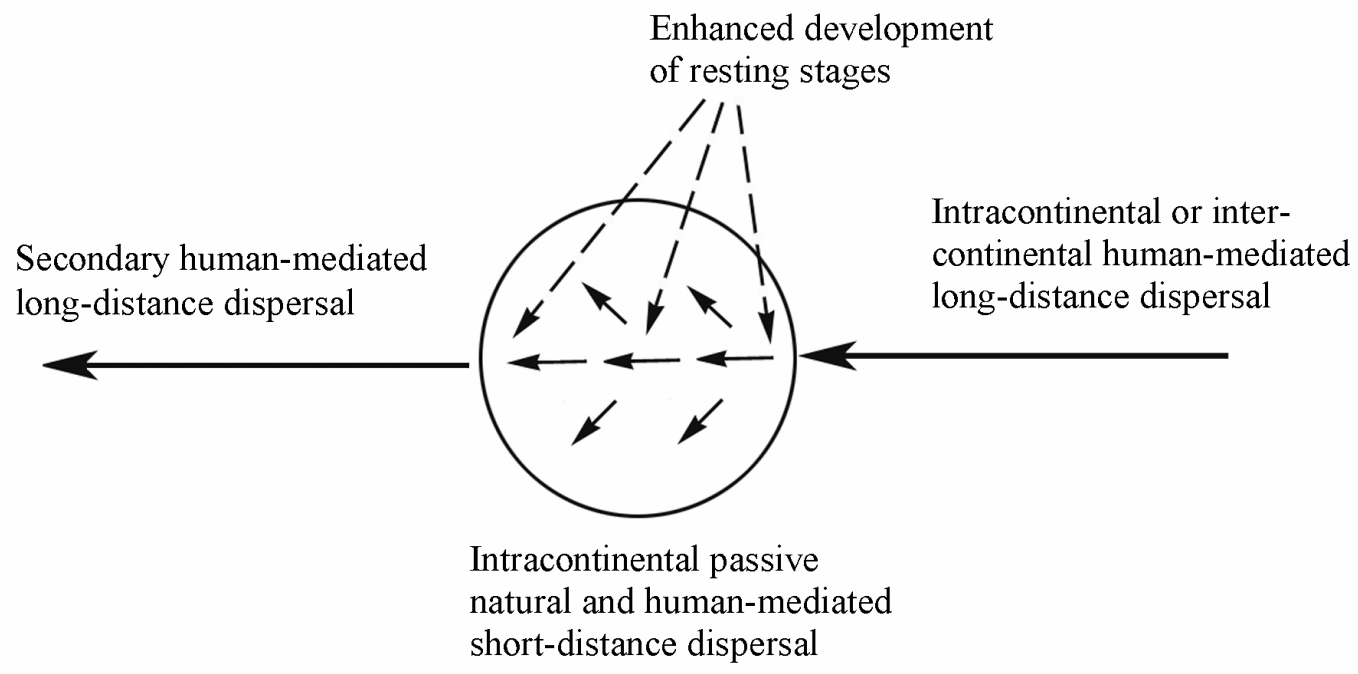

Fig. 3. Generalized model of dispersal of aquatic invertebrates with prolonged diapause.

Victoria to one of the lakes of the southern United States in 1983 can be considered as a vector of this intercontinental transfer of, most likely, ephippia of $D$. lumholtzi, which survived even quarantine treatment of fish (Havel \& Hebert 1993). In 1999, D. lumholtzi was first recorded in North American Great Lakes (Muzinic 2000), and by 2002 has become widespread across the country, with over 180 reported invasions (Shurin \& Havel 2002). Dispersal of live individuals and viable diapausing eggs of this species within the North America occurs via surface water connections, and by other vectors, specifically with live wells of recreational boats (Dzialowski et al. 2000; Havel \& Stelzleni-Schwent 2000; Shurin \& Havel 2002). Havel et al. (2002) suggested that both dispersal and local abiotic constraints jointly limit the spread of $D$. lumholtzi. Probability of invasion of this species was found as strongly negatively related to distance to source population, with highest probabilities within $30 \mathrm{~km}$ of source lakes. Long-distance dispersal of D. lumholtzi (over hundreds of $\mathrm{km}$ ) occurs much less frequent, most likely by human vector (transfer by boats).

The invasion success of $D$. lumholtzi in North American inland waters has been attributed to its tolerance of high summer temperatures (Work \& Gophen 1999) and resistance to fish predation due to defensive morphology (Swaffar \& O'Brien 1996). Lake and reservoir surveys in south-central USA have indicated a seasonal succession between native Daphnia parvula and exotic Daphnia lumholtzi, with exotic species more abundant during late summer (Johnson \& Havel 2001). However, results of in-situ experiments suggest that resource competition is not influencing the seasonal dynamics of the exotic Daphnia lumholtzi, and other factors may be involved, including different temperature cues for breaking of embrional diapause in these species (hatching of resting eggs from sediments in D. lumholtzi at warmer temperatures).

\section{CONCEPTUAL MODEL OF DISPERSAL OF AQUATIC INVERTEBRATES WITH PROLONGED DIAPAUSE}

The case studies discussed above of successful invaders into inland waters of Europe and North America suggest the possible importance of prolonged (embryonic) diapause for effective short- and long-distance (both inter- and intracontinental) dispersal in aquatic invertebrates. These invasive cladocerans were transferred across geographic barriers (Atlantic Ocean) by different human-mediated vectors possibly by means of their diapausing eggs, exposed to adverse conditions during transfer, and survived even possible ballast water management options (in case of $C$. pengoi) and quarantine treatment (in case of $D$. lumholtzi). Their following rapid short-distance and, less frequent, long-distance transfer by mainly multiple human-mediated vectors might be attributed to their life-cycle patterns in "infected" ecosystems: rapid development of large pool of diapausing eggs in populations, and, in some cases, even switching from "normal" pattern with short period of gamogenetic reproduction after prolonged period of parthenogenetic reproduction, to the early and prolonged gamogenetic reproduction. Generalized conceptual model of dispersal patterns in aquatic invertebrates with such a reproduction strategy, involving high level of development of resistant diapausing resting eggs, represented in figure 3 . Our model can be considered a variant of the human-vectored invasion model, initially suggested by MacIsaac et al. (2001) (dispersal is determined by the probability of propagule movement by humans from the source to the recipient site), with incorporation of adaptive reproduction strategies in invasive species, which increases the probability of dispersal and successful establishment in the novel ecosystem.

Rapid development of large pools of resting eggs in bottom sediments might facilitate invasion success of 
these species, and their rapid integration into local plankton communities, despite absence of "free ecological niches". Even severe competition, which is very likely for most invading species, specifically for Cercopagis pengoi in the Neva Estuary (Panov et al. 1999) and D. lumholtzi in the North American lakes studied by Johnson \& Havel (2001), cannot prevent successful establishment of the species, possessing highly adaptive strategy of rapid development of pool of diapausing eggs in the sediment egg bank.

Importance of sediment egg banks for long-term persistence of adverse environmental conditions in freshwater and marine ecosystems is well known, both for the native (De Stasio 1989; Hairston 1996; Marcus 1996; Brendonck \& De Meester 2003) and invading species. Hairston et al. (1999) found that exotic Daphnia exilis persisted for long periods only in the egg bank in lake sediments, which allowed this species to "re-invade" zooplankton community during periods of favorable environmental conditions. Resting eggs may survive in lake and marine sediments for decades and even hundreds of years (Hairston et al. 1995; Katajisto 1996; Brendonck \& De Meester 2003). Different environmental forces (physical storm driven disturbance, bioturbation of sediments by invertebrates and fish, some human activities) may result in bringing even very old resting eggs to the surface of the lake or marine sediments and expose they to the environmental hatching cues (Marcus \& Schmidt-Gengenbach 1986; Hairston et al. 1995; Kearns et al. 1996; Cáceres \& Hairston 1998).

Also, egg banks were found to play detrimental role in hampering competition in zooplankton community (Hairston 1996; Hairston 1998). Cáceres (1997) has shown that two competing species of Daphnia coexist in a large lake solely through the combined action of prolonged diapause and temporally fluctuating competitive advantage. Dormancy may act to synchronise organisms with some resource opportunity or to avoid predation and/or competition (Williams 1998). In general, species with prolonged diapause will be able to survive extreme years of no recruitment, and the egg bank creates overlapping generations between competing species via the "storage effect" of diapause: taxa that would not coexist due to competition can do so if they have sufficient generation overlap, and if they are exposed to the annually variable environments, each competitor may have greatest recruitment different years (Hairston 1996).

However, competitive advantage of diapausing aquatic invertebrates is not necessarily required to possess prolonged embryonic diapause and contribution to the egg bank. Alekseev et al. (2001) found that Cyclops vicinus invaded large Caucasian lake (Lake Sevan) in early 1980th, and since that time successfully coexisted with native copepod Cyclops abyssorum sevani. Alien copepod effectively avoids competition with the native congeneric species by possessing strong adult diapause during summer period in the anoxic sediments, which developed during last two decades as a result of anthropogenic eutrophication of the lake.

There is also evidence for evolution of life history traits of invasive microcrustaceans with respect to diapause: while the initial colonizing population appears to possess early prolonged production of diapause eggs, this characteristic erodes over time. Although in some cases a mid-summer switch towards sexual reproduction in Cladocera can be considered as an adaptation to dispersal by natural factors in marine ecosystems (see above), early prolonged production of resting eggs recorded in Bythotrephes longimanus, Cercopagis pengoi and Daphnia parvula during first years after their invasion into some lake and/or estuarine ecosystems and following fast "erosion" of this phenomenon in $B$. longimanus and $C$. pengoi can be attributed, most likely, to the rapid microevolution processes characteristic for these polymorphic species in highly variable environment.

As we suggested earlier for C. pengoi in the Neva Estuary (Krylov \& Panov 1998), switch to prolonged period of sexual reproduction in the introduced population can be attributed to some kind of the effect of "founder population", then population of alien species originated from the few specimens of the species' strain possessing "abnormal" pattern of life cycle. Probability for gamogenetic female of such strain carrying resting eggs to be pumped into ships' ballast tank during most period of population development is much higher than for the strains possessing "normal" life-cycle with comparatively short period of sexual reproduction in the autumn. "Normal" life-cycle recorded for introduced population of Bythotrephes longimanus in the reservoir in the Netherlands (Ketelaars et al. 1995), and in case of Daphnia lumholtzi invasion in North America, may support this hypothesis possibly demonstrating case studies of dispersal of "normal strains". Fast erosion of this phenomenon in Bythotrephes in Harp Lake and Cercopagis in Neva Estuary most likely related to fast evolution of the life cycle of invading species under strong press from invader-selective fish predation: by lake herring Coregonus artedii in Harp Lake (Coulas et al. 1998) and by the Baltic herring Clupea harengus membras in the Gulf of Finland (Antsulevich \& Välipakka 2000). Recently Lee (2003) showed that natural selection during invasion process plays an important role in the derivation of freshwater populations of saltwater copepod Eurytemora affinis. Also, results of modelling study by De Stasio \& Hairston (1992) suggest that variability in year-to-year environmental selection pressures may play an important role in determining the evolution of life histories.

Fast dispersal and successful establishment of several exotic zooplankton species in inland waters of Europe and North America demonstrate that the high potential for dispersal in aquatic invertebrates that develop resistant propagules might be promoted by natural 
and/or human-mediated dispersal vectors. Coupled with the ability of invertebrates with prolonged diapause to "travel in time" for persisting adverse environmental conditions and to use the "storage effect" of egg banks to avoid competition with native species or strains, these facts may question universal application of the "dispersal - gene flow paradox" suggested by De Meester et al. (2002) for freshwater zooplankton. The egg bank in lake sediments may function not only as a "buffer" against gene flow, but, in opposite, facilitate invasion success of alien species and likely even alien strains of native species, possessing adaptive life cycles with high level of gamogenetic reproduction, possibly resulting from unintentional selection by humans (human-mediated dispersal vectors). Sexual (gamogenetic) reproduction with production of resting stages in some zooplankton organisms may play an important role in contributing to local adaptation through the generation of genetic diversity (Okamura \& Freeland 2002).

\section{CONCLUSIONS}

Our review suggests that diapause in some taxa of aquatic invertebrates might play a crucial role in their dispersal and colonization success in recipient ecosystems, with human-mediated vectors of dispersal acting as a powerful selective force. Human-related selection factors may facilitate dispersal of species with high level of gamogenetic reproduction, while natural selection in novel habitats may result in fast erosion of this "founder population" effect toward "normal" life cycle with prolonged period of parthenogenetic reproduction. Alien species may play role of biological tracers, and observations of their dispersal patterns, coupled with genetic studies for identification of source populations in case of intercontinental transfers and studies of their demography in novel environments, may provide new insight in both general dispersal ecology and biology of invasions.

\section{ACKNOWLEDGMENTS}

We thank Bart De Stasio for reviewing the paper manuscript, Carol Lee for careful editing of the manuscript and valuable comments, Viktor Alekseev, Dan Minchin and John Havel for valuable discussions, Natalie Rodionova and Pavel Bolshagin for assistance in processing zooplankton samples from Neva Estuary. This study has been supported by the European Commission 6th Framework Integrated Project ALARM (contract No GOCE-CT-2003-506675).

\section{REFERENCES}

Alekseev, V.R. 1986. Role of diapause in acclimatization of crustaceans. Proceedings of GosNIORKH, 252: 61-68 (in Russian, Engl. Summary).

Alekseev, V.R. \& Y.I. Starobogatov. 1996. Types of diapause in Crustacea: definitions, distribution, evolution. Hydrobiologia, 320: 15-26.
Alekseev, V.R., K. Djenderedjan \& B. Fiks. 2001. Role of summer diapause in success of invasion of a new invertebrate predator into plankton ecosystem of a large mountain lake. Proceedings of the 9th International Conference on the Conservation and Management of Lakes (Biwako, Japan, 2001): 217-220.

Antsulevich, A. \& P.Välipakka. 2000. Cercopagis pengoi new important food object of the Baltic herring in the Gulf of Finland. Internat. Rev. Hydrobiol., 85: 609-619.

Armengol, J. 1978. Los crustaceos de plancton de los emblases espanoles. Oecologia aquatica, 3: 3-96.

Bailey, S.A., I.C. Duggan, C.D.A. van Overdijk, P.T. Jenkins \& H.J.MacIsaac. 2003. Viability of invertebrate diapausing eggs collected from residual ballast sediment. Limnol. Oceanogr., 48: 1701-1710.

Benoit, H.P., O.E. Johannsson, D.M.Warner, W.G. Sprules \& L.G. Rudstam. 2002. Assessing the impact of a recent predatory invader: The population dynamics, vertical distribution, and potential prey of Cercopagis pengoi in Lake Ontario. Limnol. Oceanogr., 47: 626-635.

Berg, D.J. \& D.W. Garton. 1988. Seasonal abundance of the exotic predatory cladoceran, Bythotrephes cederstroemi, in western Lake Erie. J. Great Lakes Res., 14: 479-488.

Berg, D.J., D.W. Garton, H.J. MacIsaac, V.E. Panov \& I.V. Telesh. 2002. Changes in genetic structure of North American Bythotrephes populations following invasion from Lake Ladoga, Russia. Freshwat. Biol., 47: 275-282.

Bilkovic, D.M. \& J.T. Lehman. 1997. Lipid concentration and size variation of Bythotrephes (Cladocera: Cercopagidae) from lakes Erie, Huron and Michigan. J. Great Lakes Res., 23: 149-159.

Bilton, D.T., J.R. Freeland \& B. Okamura. 2001. Dispersal in freshwater invertebrates. Ann. Rev. Ecol. Syst., 32: 159181.

Bohonak, A.J. \& D.G. Jenkins. 2003. Ecological and evolutionary significance of dispersal by freshwater invertebrates. Ecology Letters, 6: 783-796.

Brendonck, L., L. De Meester \& N. Hairston, Jr. (Eds). 1998. Evolutionary and ecological aspects of crustacean diapause: proceedings of the Symposium "Diapause in the Crustacea - with Invited Contributions on Non-Crustacean Taxa" held in Gent, August 24-29, 1997. Arch. Hydrobiol. Spec. Issues Advanc. Limnol., 52: 561 pp.

Brendonck, L. \& B.J. Riddoch. 1999. Wind-borne short-range egg dispersal in anostracans (Crustacea: Branchiopoda). Biol. J. Linn. Soc., 67: 87-95.

Brendonck, L. \& L. De Meester. 2003. Egg banks in freshwater zooplankton: evolutionary and ecological archives in the sediment. Hydrobiologia, 491: 65-84.

Buchan, L.A.J.\& D.K. Padilla. 1999. Estimating the probability of long-distance overland dispersal of invading aquatic species. Ecological Applications, 9: 254-265.

Bur, M.T., D.M. Klarer \& K.A. Krieger. 1986. First records of a European cladoceran, Bythotrephes cederstroemi, in Lakes Erie and Huron. J. Great Lakes Res., 12: 144-146.

Burkhard, S. 1994. Seasonal size variation in the predatory cladoceran Bythotrephes cederstroemi in Lake Michigan. Freshwat. Biol., 31: 97-108.

Cáceres , C.E. 1997. Temporal variation, dormancy, and coexistence: A field test of the storage effect. Proc. Natl. Acad. Sci. USA, 94: 9171-9175.

Cáceres, C.E. \& N.C. Hairston. 1998. Benthic-pelagic coupling in planktonic crustaceans: the role of the benthos. Arch. Hydrobiol. Spec. Issues Advanc. Limnol., 52:163174.

Cáceres, C.E. \& D.A. Soluk. 2002. Blowing in the wind: a field test of overland dispersal and colonization by aquatic invertebrates. Oecologia, 131: 402-408.

Carlton, J.T. \& J.B. Geller. 1993. Ecological Roulette: the global transport of nonindigenous marine organisms. Science, 261: 78-82 
Carlton, J.T. 1996. Pattern, process, and prediction in marine invasion ecology. Biological Conservation, 78: 97-106.

Carlton, J.T. 1999. The scale and ecological consequences of biological invasions in the World's oceans. In: O.T. Sandlund et al. (Eds), Invasive Species and Biodiversity Management. Kluwer Academic Publisher, Dordrecht: 195-212.

Charalambidou, I., H.A.M. Ketelaars \& L. Santamaria. 2003. Endozoochory by ducks: influence of developmental stage of Bythotrephes diapause eggs on dispersal probability. Diversity and Distributions, 9: 367-374.

Charlebois, P.M., M.J. Raffenberg \& J.M. Dettmers. 2001. First occurrence of Cercopagis pengoi in Lake Michigan. J. Great Lakes Res., 27: 258-261.

Coulas, R.A., H.J. MacIsaac \& W. Dunlop. 1998. Selective predation on an introduced zooplankter (Bythotrephes cederstroemi) by lake herring (Coregonus artedii) in Harp Lake, Ontario. Freshwat. Biol., 40: 343-355.

Coussement, M.A., M. de Henau, \& H.J. Dumont. 1976. Brachionus variabilis Hempel and Asplanchna girodi de Guerne, two Rotifer species new to Europe and Belgium respectively. Biol. Jb. Dodonaea, 44: 118-122.

Cristescu, M.E.A., P.D.N. Hebert, J.D.S. Witt, H.J. MacIsaac, \& I.A. Grigorovich. 2001. An invasion history for Cercopagis pengoi based on mitochondrial gene sequencing. Limnol. Oceanogr., 46: 224-229.

Cullis, K.I. \& G.E. Johnson. 1988. First evidence of the cladoceran Bythotrephes cederstroemi Schoedler in Lake Superior. J. Great Lakes Res., 14: 524-525.

De Meester, L., A. Gomez, B. Okamura \& K. Schwenk. 2002. The Monopolization hypothesis and the dispersal-gene flow paradox in aquatic organisms. Acta Oecologica, 23: 121-135.

De Stasio, B.T. Jr. 1989. The seed bank of a freshwater crustacean: copepodology for a plant ecologist. Ecology, 70: 1377-1389.

De Stasio, B.T. Jr. \& N.G. Jr. Hairston. 1992. Environmental variability and the persistence of multiple emergence strategies. Bulletin of Mathematical Biology, 54: 313-334.

Dzialowski, A.R., W.J. O'Brien \& S.M. Swaffar. 2000. Range expansion and potential dispersal mechanisms of the exotic cladoceran Daphnia lumholtzi. J. Plankton Res., 22: 2205-2223.

Einsle, U. 1978. Qualitative und quantitative Änderungen im Crustaceenplankton des Bodensee-Obersees. Arch. Hydrobiol., 82: 300-315.

Einsle, U. 1980. Weitere Untersuchungen (1976/77) über das Crustaceen-Plankton des Gnadensees (Bodensee-untersee). Schr. Ver. Gesch. Bodensees Umgeb., 98: 195-218.

Evans, M.S. 1988. Bythotrephes cederstroemi: its new appearance in Lake Michigan. J. Great Lakes Res., 14: 234-240.

Fell, P. 1998. Ecology and physiology of dormancy in sponges. Arch. Hydrobiol. Spec. Issues Advanc. Limnol., 52: $71-84$

Figuerola, J. \& A.J. Green. 2002. Dispersal of aquatic organisms by waterbirds: a review of past research and priorities for future studies. Freshwat. Biol., 47: 483-494.

Flössner, D. 2000. Die Haplopoda und Cladocera (ohne Bosminidae) Mitteleuropas. Backhuys Publishers, Leiden: 425 pp.

Flössner, D. \& K. Kraus. 1976. Zwei für Mitteleuropa neue Cladoceren-Arten (Daphnia ambigua Scourfield, 1946, und Daphnia parvula Fordyce, 1901) aus Süddeutschland. Crustaceana, 30: 301-309.

Forel, F.A. 1892. Le Leman. Tome I. F. Rouge \&Cie, Lausanne: 543 pp.

Forel, F.A. 1895. Le Leman. Tome II. F. Rouge \&Cie, Lausanne: $651 \mathrm{pp}$.

Forel, F.A. 1904. Le Leman. Tome III. F. Rouge \&Cie, Lausanne: 715 pp.

Freeland, J.R., C. Romualdi \& B. Okamura. 2000. Gene flow and genetic diversity: a comparison of freshwater bryo- zoan populations in Europe and North America. Heredity, 85: 498-508.

Frenzel, P. 1976. Nachweise zweier seltener Daphnia-Arten (Cladocera, Crustacea) in Südwestdeutschland. Mitt. Bad. Landesver. Naturk. Natursch. N.F., 11: 385-391.

Fryer, G. 1996. Diapause, a potent force in the evolution of freshwater crustaceans. Hydrobiologia, 320: 1-14.

Garton, D.W. \& D.J. Berg. 1990. Occurence of Bythotrephes cederstroemi (Schoedler 1877) in Lake Superior, with evidence of demographic variation within the Great Lakes. $J$. Great Lakes Res., 16: 148-152.

Garton, D.W., D.J. Berg \& R.J. Fletcher. 1990. Thermal tolerances of the predatory cladocerans Bythotrephes cederstroemi and Leptodora kindti: Relationship to seasonal abundance in western Lake Erie. Can. J. Fish. Aquat. Sci., 47: $731-738$.

Garton, D.W., D.J. Berg, A.N. Stoeckmann \& W.R. Haag. 1993. Biology of recent invertebrate invading species in the Great Lakes: The spiny water flea, Bythotrephes cederstroemi, and the zebra mussel, Dreissena polymorpha. Biological pollution: the control and impact of invasive exotic species. Indiana Acad. Sci.: 63-84.

Gollasch, S. \& E. Leppäkoski (Eds). 1999. Initial risk assessment of alien species in Nordic coastal waters. Nord 1999:8. Nordic Council of Ministers, Copenhagen: 244 pp.

Gollasch, S., J. Lenz, M. Dammer \& H.-G. Andres. 2000. Survival of tropical ballast water organisms during a cruise from the Indian Ocean to the North Sea. J. Plankton Res., 22: 923-937.

Gollasch, S., E. MacDonald, S. Belson, H. Botnen, J.T. Christensen, J.P. Hamer, G. Houvenaghel, A. Jermert, I. Lucas, D. Masson, T. McCollin, S. Olenin, A. Persson, I. Wallentinus, L.P.M.J. Wetsteyn \& T. Wittling. 2002. Life in ballast tanks. In: E. Leppäkoski et al. (Eds), Invasive Aquatic Species of Europe. Kluwer Academic Publisher, Dordrecht: 217-231.

Grigorovich, I.A., H.J. MacIsaac, I.K. Rivier, N.V. Aladin \& V.E. Panov. 2000. Comparative biology of the predatory cladoceran Cercopagis pengoi from Lake Ontario, Baltic Sea and Caspian Sea. Arch. Hydrobiol., 149: 23-50.

Grigorovich, I.A., R.I. Colautti, E. L. Mills, K. Holeck, A.G. Ballert \& H.J. MacIsaac. 2003. Ballast-mediated animal introductions in the Laurentian Great Lakes: retrospective and prospective analyses. Can. J. Fish. Aquat. Sci., 60: 740-756.

Hairston, N.G. Jr. 1996. Zooplankton egg banks as biotic reservoirs in changing environments. Limnol. Oceanogr., 41: 1087-1092.

Hairston, N.G. Jr. 1998. Time travelers: What's timely in diapause research? Arch. Hydrobiol. Spec. Issues Advanc. Limnol., 52: 1-15.

Hairston, N.G. Jr, R.A.Van Brunt, C.M. Kearns \& D.R. Engstrom. 1995. Age and survivorship of diapausing eggs in a sediment egg bank. Ecology, 76: 1706-1711.

Hairston, N.G. Jr \& C.E. Cáceres. 1996. Distribution of crustacean diapause: micro- and macroevolutionary pattern and process. Hydrobiologia, 320: 27-44.

Hairston, N.G. Jr \& A.J. Bohonak. 1998. Copepod reproductive strategies: life-history theory, phylogenetic pattern and invasion of inland waters. Journal of Marine Systems, 15: 23-34.

Hairston, N.G. Jr., L.P. Perry, A.J. Bohonak, M.Q. Fellows \& C.M. Kearns. 1999. Population biology of a failed invasion: Paleolimnology of Daphnia exilis in upstate New York. Limnol. Oceanogr., 44: 477-486.

Hamer, J.P. 2002. Ballast tank sediments. In: E. Leppäkoski et al. (Eds), Invasive Aquatic Species of Europe. Kluwer Academic Publisher, Dordrecht: 232-234.

Havel, J.E. \& P.D.N. Hebert. 1993. Daphnia lumholtzi in North America: Another exotic zooplankter. Limnol. Oceanogr., 38: 1823-1827. 
Havel, J.E., W.R. Mabee \& J.R. Jones. 1995. Invasion of the exotic cladoceran Daphnia lumholtzi into North American reservoirs. Can. J. Fish. Aquat. Sci., 52: 151-160.

Havel, J.E. \& J. Stelzleni-Schwent. 2000. Zooplankton community structure: The role of dispersal. Verh. int. Ver. Limnol., 27: 3264-3268.

Havel, J.E., J.K. Colbourne \& P.D.N. Hebert. 2000. Reconstructing the history of intercontinental dispersal of Daphnia lumholtzi by use of genetic markers. Limnol. Oceanogr., 45: 1414-1419.

Havel, J.E., J.B. Shurin \& J.R. Jones. 2002. Estimating dispersal from patterns of spread: spatial and local control of lake invasions. Ecology, 83: 3306-3318.

Havel, J.E. \& J.B. Shurin. 2004. Mechanisms, effects, and scales of dispersal in freshwater zooplankton. Limnol. Oceanogr., 49: 1229-1238.

Hebert, P.D.N. \& M.E.A. Cristescu. 2002. Genetic perspectives on invasions: the case of the Cladocera. Can. J. Fish. Aquat. Sci., 59: 1229-1234.

Herbst, H.-V. \& D. Anders. 1987. Ein eingeschleppter Kleinkrebs (Crustacea, Cladocera) im Bergischen Land. Natur am Niederrhein, 2: 26-30.

Hobæk, A., M. Manca \& T. Andersen. 2002. Factors influencing species richness in lacustrine zooplankton. Acta Oecologica, 23: 155-163.

Horne, D.J. \& K. Martens. 1998. An assessment of the importance of resting eggs for the evolutionary success of Mesozoic non-marine cypridoidean Ostracoda (Crustacea). Arch. Hydrobiol. Spec. Issues Advanc. Limnol., 52: 549-561.

Horvath, T.G., R.L. Whitman \& L.L. Last. 2001. Establishment of two invasive crustaceans (Copepoda: Harpacticoida) in the nearshore sands of Lake Michigan. Can. J. Fish. Aquat. Sci., 58: 1261-1264.

Hrbáček, J. 1987. Systematics and biogeography of Daphnia species in the northern temperate regions. In: Peters, R.H. \& R. de Bernardi (Eds). Daphnia, Mem. Ist. ital. Idrobiol., 45: $37-76$

Jarnagin, S.T., B.K. Swan \& W.C. Kerfoot. 2000. Fish as vectors in the dispersal of Bythotrephes cederstroemi: diapausing eggs survive passage through the gut. Freshwat. Biol., 43: 579-589.

Jenkins, D.G. 1995. Dispersal-limited zooplankton distribution and community composition in new ponds. Hydrobiologia, 313 \& 314: 15-20

Jenkins, D.G. \& M.O. Underwood. 1998. Zooplankton may not disperse readily in wind, rain, or waterfowl. Hydrobiologia, 387 \& 388: 15-21.

Jin, E.H. \& W.G. Sprules. 1990. Distribution and abundance of Bythotrephes cederstroemi (Cladocera: Cercopagidae) in the St. Lawrence Great Lakes. Verh. int. Ver. Limnol., 24: 383-385.

Johannsson, O.E., E.L. Mills \& R. O'Gorman. 1991. Changes in the nearshore and offshore zooplankton communities in Lake Ontario - 1981-88. Can. J. Fish. Aquat. Sci., 48: 1546-1557.

Johnson, J.L. \& J.E. Havel. 2001. Competition between exotic and native Daphnia: In situ experiments. J. Plankton Res., 23: 373-387.

Johnson, L.E. \& J.T. Carlton. 1996. Post-establishment spread in large-scale invasions: dispersal mechanisms of the zebra mussel Dreissena polymorpha. Ecology, 77: 16861690.

Johnson, L.E., A. Ricciardi \& J.T. Carlton. 2001. Overland dispersal of aquatic invasive species: a risk assessment of transient recreational boating. Ecol. Appl., 11: 1789-1799.

Karlson, R.H. 1992. Divergent dispersal strategies in the freshwater bryozoan Plumatella repens - ramet size effects on statoblast numbers. Oecologia, 89: 407-411.

Katajisto, T. 1996. Copepod eggs survive a decade in the sediments of the Baltic Sea. Hydrobiologia, 320: 153-159.
Kearns, C.M., N.G. Hairston \& D.V. Kesler. 1996. Particle transport by benthic invertebrates: its role in egg bank dynamics. Hydrobiologia, 332: 63-70.

Ketelaars, H.A.M. \& L. Gille. 1994. Range extension of the predatory cladoceran Bythotrephes longimanus Leydig 1860 (Crustacea, Onychopoda) in Western Europe. Netherlands Journal of Aquatic Ecology, 28: 175-180.

Ketelaars, H.A.M., A.J. Wagenvoort \& R.F. Herbst. 1995. Life history characteristics and distribution of Bythotrephes longimanus Leydig (Crustacea, Onychopoda) in the Biesbosch reservoirs. Hydrobiologia, 307: 239-251.

Korovchinsky, N.M \& O.S. Boikova. 1996. The resting eggs of Ctenopoda (Crustacea: Branchiopoda): a review. Hydrobiologia, 320: 131-140.

Krylov, P.I. \& V.E. Panov. 1998. Resting eggs in the life cycle of Cercopagis pengoi, a recent invader of the Baltic Sea. Arch. Hydrobiol. Spec. Issues Advanc. Limnol., 52: 383392.

Krylov, P.I., D.E. Bychenkov, V.E. Panov, N.V. Rodionova \& I.V. Telesh.1999. Distribution and seasonal dynamics of the Ponto-Caspian invader Cercopagis pengoi (Crustacea, Cladocera) in the Neva Estuary (Gulf of Finland). Hydrobiologia, 393: 227-232.

Krylov, P.I., P.V. Bolshagin, D.E. Bychenkov, E.N. Naumenko, V.E. Panov \& Y.Y. Polunina. (2004). Invasions of predatory planktonic cladocerans and possible causes of their success. In: A.F. Alimov, N.G. Bogutskaya (Eds). Biological Invasions in Aquatic and Terrestrial Ecosystems. KMK Scientific Press Ltd., Moscow: 99-128 (in Russian).

Laxson, C.L., K.N. McPhedran, J.C. Makarewicz, I.V. Telesh \& H.J. MacIsaac. 2003. Effects of the non-indigenous cladoceran Cercopagis pengoi on the lower food web of Lake Ontario. Freshwat. Biol., 48: 2094-2106.

Lange, C. \& R. Cap. 1986. Bythotrephes cederstroemi (Schödler) (Cercopagidae: Cladocera): a new record for Lake Ontario. J. Great Lakes Res., 12: 142-143.

Lee, C.E. 1999. Rapid and repeated invasions of fresh water by the saltwater copepod Eurytemora affinis. Evolution, 53: 1423-1434.

Lehman, J.T. 1987. Palearctic predator invades North American Great Lakes. Oecologia (Berlin), 74: 478-480.

Leppäkoski, E., S. Gollasch \& S. Olenin (Eds). 2002. Invasive Species of Europe. Distribution, impacts and management. Kluwer Academic Publishers, Dordrecht, The Netherlands: $533 \mathrm{pp}$.

MacIsaac, H.J., I.A. Grigorovich, J.A. Hoyle, N.D. Yan \& V.E. Panov. 1999. Invasion of Lake Ontario by the PontoCaspian cladoceran predator Cercopagis pengoi. Can. J. Fish. Aquat. Sci., 56: 1-5.

MacIsaac, H.J., I.A. Grigorovich \& A. Ricciardi. 2001. Reassessment of species invasions concepts: the Great Lakes basin as a model. Biological Invasions, 3: 405-416.

MacIsaac, H.J., H.A.M. Ketelaars, I.A. Grigorovich, C. Ramcharan \& N.D. Yan. 2000. Modeling Bythotrephes longimanus invasions in the Great Lakes basin based on its European distribution. Arch. Hydrobiol., 149: 1-21.

MacIsaac, H.J., J. Borbely, J. Muirhead \& P. Graniero. 2004. Backcasting and forecasting biological invasion of inland lakes. Ecol. Appl., 14: 773-883.

Maguire, B. Jr. 1963. The passive dispersal of small aquatic organisms and their colonization of isolated bodies of water. Ecol. Monogr., 33: 161-185.

Makarewicz, J.C., I.A. Grigorovich, E. Mills, E. Damaske, M.E. Cristescu, W. Pearsall, M.J. LaVoie, R. Keats, L. Rudstam, P. Hebert, H. Halbritter, T. Kelly, C. Matkovich, \& H.J. MacIsaac. 2001. Distribution, fecundity, and genetics of Cercopagis pengoi (Ostroumov) (Crustacea, Cladocera) in Lake Ontario. J. Great Lakes Res., 27: 19-32.

Makarewicz, J.C., E. Damaske, C. Laxson, H.J. MacIsaac \& I.A. Grigorovich. 2003. Seasonal and vertical distribution, 
food web dynamics and contaminant biomagnification of Cercopagis pengoi in Lake Ontario. Proc. $11^{\text {th }}$ Annual Invasive Species Conference: 132-141.

Makrushin, A.V. 1984. On incomplete consistency between the life cycles of marine cladocerans Podon leuckarti and Evadne nordmanni (Crustacea) and seasonal environmental factors. Ekol. Morya (Kiev), 18: 59-62 (In Russian Engl. Summary).

Maier, G. 1996. Daphnia invasion: population dynamics of Daphnia assemblages in two eutrophic lakes with particular reference to the introduced alien Daphnia ambigua. J. Plankton Res., 18: 2001-2015.

Marcus, N.H. 1996. Ecological and evolutionary significance of resting eggs in marine copepods: past, present and future. Hydrobiologia, 320: 141-152.

Marcus, N.H. \& J. Schmidt-Gengenbach. 1986. Recruitment of individuals into the plankton: The importance of bioturbation. Limnol. Oceanogr., 31: 206-210.

McKenzie, K.G. \& A. Moroni. 1986. Man as an agent of crustacean passive dispersal via useful plants - exemplified by Ostracoda ospiti esteri of the Italian ricefields ecosystem - and implications arising therefrom. Journal of Crustacean Biology, 6: 181-198.

Minchin, D. \& S. Gollasch. 2002. Vectors - how exotics get around. In: E.Leppäkoski et al. (Eds), Invasive Aquatic Species of Europe. Kluwer Academic Publisher, Dordrecht: 183-192.

Mordukhai-Boltovskoi, Ph.D. \& V.L. Galinskiy. 1974. On further distribution of the Caspian Polyphemoidea in the reservoirs of the Ponto-Caspian rivers. Biol. Vnutr. Vod. Inform. Byul., 21: 40-44 (in Russian).

Mordukhai-Boltovskoi, Ph.D. \& I.K. Rivier. 1987. Predatory cladocerans Podonidae, Polyphemidae, Cercopagidae, and Leptodoriade of the world fauna. Keys to the fauna of the USSR. Zoological Institute of the Academy of Sciences of the USSR. 148. Nauka press Leningrad: $183 \mathrm{pp}$ (in Russian).

Muzinic, C.J. 2000. First record of Daphnia lumholtzi Sars in the Great Lakes. J. Great Lakes Res., 26: 352-354.

Okamura, B. \& J.R.Freeland. 2002. Gene flow and the evolutionary ecology of passively dispersing aquatic invertebrates. In: Bullock, J.M., R.E. Kenward \& R.S. Hails (Eds). Dispersal Ecology. Blackwell Science Publishing, Oxford: 194-216.

Ojaveer, H. \& A. Lumberg. 1995. On the role of Cercopagis pengoi (Ostroumov) in Pärnu Bay and the NE part of the Gulf of Riga ecosystem. Proc. Estonian Acad. Sci. Ecol., 5: $20-25$.

Ojaveer, H., A. Lankov \& A. Lumberg. 2000. Consequences of invasion of a predatory cladoceran. ICES C.M. 2000/U:16.

Ojaveer, H., L.A. Kuhns, R.P.Barbiero, \& M.L.Tuchman. 2001. Distribution and population characteristics of Cercopagis pengoi in Lake Ontario. J. Great Lakes Res., 27: $10-18$.

Olenin, S. \& E. Leppäkoski (Eds). 2001. Baltic Sea Alien Species Database. Alien Species Directory. Internet: http://www.ku.lt/nemo/mainnemo.htm

Panov, V.E., P.I. Krylov \& I.V. Telesh. 1996. The Caspian predatory cladoceran Cercopagis pengoi invades the Gulf of Finland. BFU Research Bulletin, 2: 80-81.

Panov, V.E., P.I. Krylov \& I.V. Telesh. 1999. The St. Petersburg harbour profile. In: Gollasch, S. \& E. Leppäkoski (Eds). Initial risk assessment of alien species in Nordic coastal waters. Nord 1999:8. Nordic Council of Ministers, Copenhagen: 225-244.

Panov, V.E., D.E.Bychenkov, N.A. Berezina \& A.A. Maximov. 2003. Alien species introductions in the eastern Gulf of Finland: current state and possible management options. Proc. Estonian Acad. Sci. Biol. Ecol., 52: 254-267.
Petkovski, S.T. 1990. Nachweise von Daphnia pulicaria Forbes, 1893 emend. Hrbáček (1959) und Daphnia parvula Fordyce, 1901 in Jugoslawien (Crustacea, Cladocera, Anomopoda). Mitt. Hamb. Zool. Mus. Inst., 87: 261-272.

Pothoven, S.A., G.L. Fahnenstiel \& H.A. Vanderploeg. 2003. Population characteristics of Bythotrephes in Lake Michigan. J. Great Lakes Res., 29: 145-156.

Proctor, V.W. 1964. Viability of crustacean eggs removed from ducks. Ecology, 45: 656-658.

Proctor, V.W., C.R. Malone \& V.L. DeVlaming. 1967. Dispersal of aquatic organisms: viability of disseminules recovered from the intestinal tract of captive killdeer. Ecology, 48: 672-676.

Riccardi, N., G. Giussani, F. Margaritora \& B. Couchaud. 2004. Population dynamics of the pioneer population of Daphnia parvula, Fordyce during the invasion of Lake Candia (Northern Italy). J. Limnol., 63: 44-52.

Schaber, P. 1983. Erstnachweis von Daphnia parvula Fordyce 1901 in Tirol (Oesterreich) (Crustacea, Cladocera). Ber. Nat. - Med. Verein Innsbruck, 70: 61-66.

Schrimpf, A. \& C. Steinberg. 1982. Weitere Fundorte der für Süddeutschland neu nachgewiesen Cladocere Daphnia parvula Fordyce 1901 (Crustacea, Phyllopoda). Arch. Hydrobiol., 94: 372-381.

Shanks, A.L., B.A. Grantham \& M.H. Carr. 2003. Propagule dispersal distance and the size and spacing of marine reserves. Ecol. Appl., 13(1) Supplement: S159-S169.

Shurin, J.B. 2000. Dispersal limitation, invasion resistance, and the structure of pond zooplankton communities. Ecology, 81: 3074-3086.

Shurin, J.B. \& J.E. Havel. 2002. Hydrologic connections as dispersal routes for the spread of the exotic cladoceran Daphnia lumholtzi. Biological Invasions, 4: 431-439.

Sprules, W.G., H.P. Riessen \& E.H. Jin. 1990. Dynamics of the Bythotrephes invasion of the St. Lawrence Great Lakes. J. Great Lakes Res., 16: 346-351.

Stará, L., J. Sed'a \& J. Kubečka. 2002. The analysis of zooplankton status in Rimov Reservoir and its comparison with old data. Hydrobiological Institute AS CR (Eds): 320321.

Straile, D. \& A. Hälbich. 2000. Life history and multiple antipredator defenses of an invertebrate pelagic predator, Bythotrephes longimanus. Ecology, 81: 150-163.

Swaffar, S.M. \& W.J. O'Brien. 1996. Spines of Daphnia lumholtzi create feeding difficulties for juvenile bluegill sunfish (Lepomis macrochirus). J. Plankton Res., 18: 1055-1061.

Taylor, D.J., T.L. Finston \& P.D.N. Hebert. 1998. Biogeography of a widespread freshwater crustacean: pseudocongruence and cryptic endemism in the North American Daphnia laevis complex. Evolution, 52: $1648-1670$

Therriault, T.W., I.A. Grigorovich, D.D. Kane, E.M. Haas, D.A. Culver \& H.J. MacIsaac. 2002. Range expansion of the exotic zooplankter Cercopagis pengoi (Ostroumov) into western Lake Erie and Muskegon Lake. J. Great Lakes Res., 28: 698-701.

Williams, D.D. 1998. The role of dormancy in the evolution and structure of temporary water invertebrate communities. Arch. Hydrobiol. Spec. Issues Advanc. Limnol., 52: 109-124.

Work, K.A. \& M. Gophen. 1999. Factors which affect the abundance of an invasive cladoceran, Daphnia lumholtzi, in U.S. reservoirs. Freshwat. Biol., 42: 1-10.

Yan, N.D. \& T.W. Pawson. 1997. Changes in the crustacean zooplankton community of Harp Lake, Canada, following invasion by Bythotrephes cederstroemi. Freshwat. Biol., 37: 409-425.

Yan, N.D. \& T.W. Pawson. 1998. Seasonal variation in the size and abundance of the invading Bythotrephes in Harp Lake, Ontario, Canada. Hydrobiologia, 361: 157-168. 
Yan, N.D., W.I. Dunlop, T.W. Pawson \& L.E. MacKay. 1992. Bythotrephes cederstroemi (Schoedler) in Muskoka Lakes: first records of the European invader in inland lakes in Canada. Can. J. Fish. Aquat. Sci., 49: 422-426.

Yan, N.D., A. Blukacz, W.G. Sprules, P.K. Kindy, D. Hackett, R.E. Girard \& B.J. Clark. 2001. Changes in zooplankton and the phenology of the spiny water flea, Bythotrephes, following its invasion of Harp Lake, Ontario, Canada. Can. J. Fish. Aquat. Sci., 58: 2341-2350.
Yan, N.D, R. Girard \& S. Boudreau. 2002. An introduced invertebrate predator (Bythotrephes) reduces zooplankton species richness. Ecology Letters, 5: 481-485.

Zaitsev, Yu. \& B. Öztürk (Eds). 2001. Exotic species in the Aegean, Marmara, Black, Azov and Caspian Seas. Published by Turkish Marine Research Foundation, Istanbul, Turkey: $267 \mathrm{pp}$. 